\title{
Hepatitis and HIV Co-infection at University of Gondar Specialized Referral Hospital: Northwest Ethiopia
}

\author{
Meseret Ayelign' \\ Melak Aynalem (iD) ${ }^{2}$ \\ Nega Berhane 3 \\ 'Department of Molecular Biology, \\ Specialized Referral Hospital, University \\ of Gondar, Gondar, Ethiopia; \\ ${ }^{2}$ Department of Hematology and \\ Immunohematology, School of \\ Biomedical and Laboratory Sciences, \\ College of Medicine and Health Science, \\ University of Gondar, Gondar, Ethiopia; \\ ${ }^{3}$ Department of Biotechnology, College \\ of Natural Sciences, University of \\ Gondar, Gondar, Ethiopia
}

Background: Viral infections are the most common diseases. Of them, human immunodeficiency virus (HIV), hepatitis B viruses (HBV), and hepatitis $\mathrm{C}$ viruses (HCV) are common. When HBV or HCV becomes co-morbid with HIV, they lead to severe forms of a disease and rapid death.

Objective: This study aimed to determine the seroprevalence and associated factors of HBV and HCV among HIV-positive study participants.

Methods: A cross-sectional study was conducted among 81 individuals, and a nonrandomized purposive sampling technique was used. From each study participant, sociodemographic and clinical data were gathered by using a pretested questionnaire and data collection sheet, respectively. Further, a venous blood sample was collected for viral load count, and HBV and HCV determination. To keep the quality of test results, commercially prepared quality control samples were used. The data were entered to EPI-Info version 7 and analyzed by using SPSS version 20. The descriptive data were summarized in percentages, median, and IQR. Logistic regression was analyzed to determine associated factors. To say the data were statistically significant, the $p$-values should be less than 0.05 .

Results: A total of 81 study participants were included. Of them, 56.8\% (46/81) and 67.9\% (55/81) were female and urban residents, respectively. The prevalence of hepatitis coinfection was $21 \%(95 \% \mathrm{CI}: 17 \%, 23 \%)$. Further, the prevalence of $\mathrm{HBV} / \mathrm{HIV}$ and $\mathrm{HCV} /$ HIV was $13.5 \%$ (95\% CI: $10.5 \%, 16.5 \%)$ and $8.6 \%$ (95\% CI: $5.6 \%, 11.6 \%)$, respectively. Wise use of highly active antiretroviral therapy (HAART) $0.01(0.00,0.213)$ was a preventive factor to hepatitis infection.

Conclusion and Recommendation: The HBV and HCV co-infection among HIVpositive patients was a significant public health concern. Also, having wise use of HAART can reduce exposure to hepatitis co-infection. Therefore, clear strategies on hepatitis screening and wise use of HAART to HIV would be critical.

Keywords: seroprevalence, HBV, HCV, HIV, Gondar, Ethiopia

\section{Background}

Human immunodeficiency virus and hepatitis are common viral infections. ${ }^{1}$ Globally, in 2015, HIV affects 38.6 million individuals, whereas both HBV and HCV affect 570 million individuals. Of them, about 400 million cases are due to HBV. From the HIV-positive adult population, 2-4 million were co-infected with HBV, whereas HCV co-infection affects around 4-5 million cases, a greater number than HBV co-infection. ${ }^{2}$ Roughly $10-20 \%$ of HIV-infected patients are expected to
Correspondence: Melak Aynalem Department of Hematology and Immunohematology, School of Biomedical and Laboratory Sciences, College of Medicine and Health Science, University of Gondar, P.O. Box 196, Gondar, Ethiopia Tel +251912692619

Email melak.aynalemI234@gmail.com 
have HBV co-infection. ${ }^{3}$ The co-infected patients will have poor prognosis regarding disease progression and become immunocompromised. ${ }^{4}$ So, $\mathrm{HBV}$ and $\mathrm{HCV}$ coinfection is a public health problem of utmost importance. ${ }^{5}$

In the most affected area of the world, hepatitis and HIV co-infections have an overlapped distribution. ${ }^{6}$ Studies also showed that there is escalating disease distribution of HIV and hepatitis co-infection in African populations. $^{7-9}$ As regards global HIV infection incidence, about $70 \%$ of the cases were reported in sub-Saharan Africa. ${ }^{10}$ Similarly, Ethiopia is also severely affected by HIV infection, with a $2.1 \%$ prevalence in the total population, and Ethiopia is also considered an endemic area for both $\mathrm{HBV}$ and $\mathrm{HCV}$ infections. ${ }^{11}$

Human immunodeficiency virus is a major cause of death throughout the world. ${ }^{12}$ The virus mainly affects the immune system cells and rapidly lowers the immune privilege activity of cells. Within a short time, it progresses into acquired immune deficiency syndrome (AIDS), which leads to susceptibility to many opportunistic diseases. Consequently, it leads to death. ${ }^{13}$ Also, HBV is a deoxynucleic acid virus that replicates in liver cells. ${ }^{14}$ Then, the virus will damage the organ by a high immune response, and it causes acute and chronic liver disease. ${ }^{15}$ The hepatitis virus can be categorized as hepatitis A up to $\mathrm{E}$ viruses. But $\mathrm{HBV}$ and $\mathrm{HCV}$ are the most severe diseases and widespread forms of chronic hepatitis worldwide. ${ }^{16}$

Patients with HIV infection are a risk group for HBV and HVC co-infection, especially when the virus reaches the AIDS stage. ${ }^{17}$ Due to the shared risk factors, HIVinfected patients are more likely to be infected with hepatitis. ${ }^{18}$ The risk factors are due to their similar transmission methods; these are: having unsafe sex, mother-tochild transmission, sharing sharp materials, having shared intravenous drugs, and donating HIV- and hepatitisinfected blood. ${ }^{19,20}$ Also, the HIV infection can cause a reduction of the immunity of the host that leads to the reactivation of the hepatitis virus. Furthermore, due to side effects of the medications that are given to HIV patients, the liver disease can be aggravated. As a result, patients with HBV/HIV co-infection are more susceptible to death than non-co-infected patients. ${ }^{14}$ The rapid mortality is due to hematological problems, organ failure, and chronic liver disease. Chronic liver disease can also result in cancer. ${ }^{21}$

However, there is limited academic research in this area, and no recent research has been carried out in the study area that can show the distribution of the disease causes and the association between both co-infections and viral load level. Therefore, we assessed the seroprevalence and associated factors of hepatitis among adult HIVpositive patients attending University of Gondar Specialized Referral Hospital (UoG-SRH).

\section{Study Setting and Study Population}

To determine the seroprevalence of hepatitis co-infection with HIV, a cross-sectional study design was used. This study was conducted in UoG-SRH found in Gondar town. A total population of 207,044 are living in the town. Of them, 108,924 were female. ${ }^{22}$ The projected population number in 2020 is estimated as $362,000{ }^{23}$ The UoGSRH is a teaching hospital; it is the oldest academic institution in Ethiopia and provides medical services for more than 7 million people. ${ }^{24}$

In the current study, 81 study participants were included. Their age was ranged from 16 up to 72 years old. Study participants with HIV infection and attending ART treatment center were considered as the study population. The outcome of interest was hepatitis co-infection, and the independent variables were age, sex, residence, alcohol drinking, cigarette smoking, presence of fever and chill, sharing sharp materials, viral load, condom usage, the wise use of HAART, and drug abuse.

\section{Sample Size and Sampling Techniques}

The number of 81 as a study population was determined by a single population proportion formula by assuming the prevalence of HBV co-infection as $5.6 \% .{ }^{25}$ To select those study participants a convenient sampling technique was applied.

\section{Data Collection Laboratory Procedures}

Data were collected by professional nurses and laboratory technologists including socio-demography, clinical, anthropometric, and laboratory measurements. First, the data collectors were trained in the aim of the study by the principal investigators. The data collection procedure was carried out under the supervision of the principal investigator.

\section{Socio-Demographic and Clinical Data Collection}

A pre-tested structured questionnaire, as well as a data collection sheet, was used to collect sociodemographic and behavioral data like age, sex, residence, alcohol drinking, cigarette smoking, presence of fever and chill, sharing sharp materials, not using a condom, drug abuse, and wise use of HAART, and a detailed history of the patient was 
collected by a professional nurse. To keep the quality of the data, the questionnaire was written in the English language, then it was converted into the local language (Amharic), then back into the English language. To improve the quality of the data the questionnaires were pre-tested in the Meraki health center before the study began. The data collectors were trained professional nurses and laboratory technologists under the supervision of investigators.

\section{Blood Sample Collection}

First, the study participants were asked to give venous blood samples. Then, venous blood samples were collected by a laboratory technologist. A total of $8 \mathrm{~mL}$ venous blood was collected by using an evacuated collection system for the viral load count, and HBV and HCV tests. The blood was dispensed into an ethylene diamine tetra acetic acid (EDTA) anticoagulant test tube and a serum separator tube for the viral load count and hepatitis virus detection, respectively. To keep the quality of blood samples, the blood was collected through standardized and sterile techniques by trained professional laboratory technologists.

\section{Viral Load Determination}

Viral load was counted by using an automated COBAS AmpliPrep/COBAS TaqMan HIV-1 Qual Test Volume 1.1 (Roche Molecular System, Inc., Branchburg, NJ, USA). The TaqMan machine assay uses the RT-PCR principle. It has sequential steps; these are sample preparation, reverse transcriptase, PCR amplification, and finally the counting of target RNA. To perform a viral load count $1100 \mu \mathrm{L}$ of plasma per participant was extracted by centrifuging the 5 milliliters of venous blood. Then, the amount of HIV target sequence in the study participant's blood was amplified at each cycle and counted by the fluorescent-labeled oligonucleotide probes in the device. To keep the quality of test results, all manufacturer precautions were kept and commercially prepared quality control samples were run every day.

\section{HBV Detection}

Hepatitis B virus is tested for by rapid test cassette (ACON Laboratories, Inc., San Diego, USA). The hepatitis B surface antigen (HBsAg) rapid test cassette uses the chromatographic method which uses a double antibody-sandwich method. The chromatography paper is pre-coated with an antibody for HBsAg antigen specifically on the test line. If the HBsAg is found in the sample, it will migrate by capillary action and form a red line on the test area and the control area. If the HBsAg was not found, a red line will appear on the control area only. To keep its quality, commercial known control samples were also properly warmed, mixed, and used to assure rapid test kit performance.

\section{HCV Detection}

Hepatitis $\mathrm{C}$ virus was tested for by using the $\mathrm{HCV}$ antibody test cassette (Xiamen Boson Biotech Co., Ltd, Xiamen, Fujian, China). Rapid HCV antibody test is also a chromatographic-based test method. The cassette is labeled with HCV antigen on the test region, and the secondary antibody to HCV antibody was labeled in the control region. Then, if the patient sample contains the anti-HCV antibody it will migrate by capillary action and the antibody will react to pre-coated antigen and secondary antibody in the test region and control region, respectively. Finally, it will form a red line on both sites. If it was negative, only a reaction occurred in the control region. The quality of the test result was kept by using a known control sample.

\section{Data Entry and Analysis}

First, the data were cleared by Epi-Info Version 7. Then, the data were extracted to the SPSS version 20 software for the data analysis. Then the data distribution was checked by the Shapiro-Wilk test. Then, descriptive statistics were summarized and presented in the form of figures and tables. The data were reported with mean and standard deviation (SD) for normally distributed data and median and interquartile range (IQR) for skewed data. The association of the independent variable with the categorical outcome variable was measured by calculating the odds ratio with a $95 \%$ confidence interval using bivariate and multivariate logistic regression analysis. Variables having a $p$-value of less than 0.2 were selected for multivariate logistic regression analysis. To say a value was statistically significant the $p$-value must be $<0.05$. Further, to show the strength of the association, the odds ratio with a $95 \%$ confidence interval was used.

\section{Results}

\section{Socio-Demographic and Clinical Characteristics of Study Participants}

In the current study, 81 HIV-positive study participants were included. The median age was 36 (IQR=18). Out of them, female study participants accounted for $56.8 \%$ (46/ $81)$, while $43.2 \%(35 / 81)$ were males. The age 
classification showed that $51.6 \%(42 / 81)$ of the study group were $<35$ years old, and $67.9 \%(55 / 81)$ of participants were from urban residences.

At the time of data collection, about $88.9 \%$ (72/81) of study participants were wisely using their HAART treatment, and 14.8\% (12/81) of HIV-positive participants presented with diarrhea followed by both chills and fever $11.1 \%(9 / 81)$. No condom usage was seen among 33.3\% (27/81) of co-infected study participants.

\section{The Seroprevalence of HBV and HBV}

In this current study, the overall seroprevalence of hepatitis virus (HBV or HCV) infection among HIV-positive patients attending at UoG-SRH was $21 \%$ (17/81). Furthermore, among hepatitis co-infected patients, the prevalence of HBV was found to be $13.6 \%$ (11/81). Among HBV co-infected participants, $45.45 \%$ were males and $54.55 \%$ of them were females. Also, the highest $54.55 \% \mathrm{HBV}$ co-infection was found in the age groups of $<35$ years (Figure 1).

The seroprevalence of HCV in HIV-positive participants is $8.6 \%(7 / 81)$. Among those participants, $\mathrm{HCV}$ is more prevalent in males $(85.7 \%)$ than in females $(14.3 \%)$. In addition, the highest HCV seropositivity was seen in participants who come from an urban area (57.1\%). Furthermore, co-infection of HBV plus HCV among HIV-infected study participants amounted to $1.23 \%(1 / 81)$ (Table 1$)$.

From a total of $21 \%(17 / 81)$ hepatitis-infected individuals, $1.23 \%(1 / 81)$ of the study participants developed all three viral infections (HBV/HCV/HIV).

\section{Viral Load Count Among Study Participants}

Among the 81 study participants, the HIV viral load count was $>1000$ copies $/ \mathrm{mL}$ in $51.8 \%(42 / 81)$, while a viral load

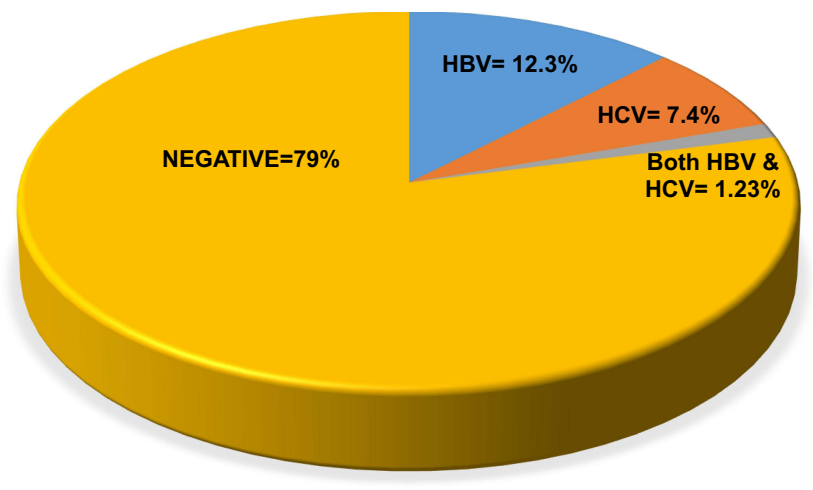

Figure I Prevalence of HBV and HCV co-infection among HIV-infected study participants at UoG-SRH 2020. count of $\leq 1000$ copies $/ \mathrm{mL}$ was seen in $48.2 \%(39 / 81)$. Among hepatitis-infected individuals about $88.2 \%$ (15/ 17) study participants had $>1000$ viral load count (Table 2).

\section{Factors Associated with $\mathrm{HBV}$ and $\mathrm{HCV}$ Co-Infection}

To determine the factor associated with hepatitis coinfection we have performed a bivariate logistic regression analysis. In this phase variables with gender $(\mathrm{COR}=1.11$; 95\% CI: $0.37,3.29)$, age in years $(\mathrm{COR}=0.91 ; 95 \% \mathrm{CI}$ : $0.31,2.70)$, residence $(\mathrm{COR}=0.60 ; 95 \% \mathrm{CI}: 0.20,1.82)$, cigarette smoker $(\mathrm{COR}=5.27$; 95\% CI: $1.43,19.39)$, alcohol user $(\mathrm{COR}=4.87 ; 95 \% \mathrm{CI}: 1.56,15.25)$, no condom usage $(\mathrm{COR}=10.13 ; 95 \% \mathrm{CI}$ : $0.04,0.42)$, sharing of sharp materials $(\mathrm{COR}=3.39 ; 95 \% \mathrm{CI}: 0.92,12.52)$, abstinence $(\mathrm{COR}=0.16 ; 95 \% \mathrm{CI}: 0.05,0.53)$, and wise use of HAART treatment $(\mathrm{COR}=0.05 ; 95 \% \mathrm{CI}: 0.01,0.18)$ showed an association with hepatitis (HBV or HCV) co-infection.

Then, variables with a $p$-value of less than 0.2 (gender, age in years, residence, cigarette smoker, and alcohol user, no condom usage, sharing of sharp materials, abstinence, and wise use of HAART) were further analyzed with multivariate analysis regression. However, in multivariable analysis, only wise use of HAART (AOR $=0.01 ; 95 \% \mathrm{CI}$ : $0.001,0.213$ ) was significantly associated with hepatitis co-infection (HBV/HCV) (Table 1).

\section{Discussion}

Hepatitis virus infection, especially $\mathrm{HBV}$ and $\mathrm{HCV}$, is frequently found as a co-infection in HIV-positive patients, causing complications and leading to death. Globally, about $10 \%$ of HIV-infected individuals developed chronic HBV coinfection. But in hepatitis-endemic areas up to $20 \%$ of HIVinfected individuals have developed HBV co-infection. Therefore, this study determined the seroprevalence and associated factors of hepatitis co-infection in North West Ethiopia.

In this study, the overall seroprevalence of hepatitis coinfection was $21 \%$ (95\% CI: $18 \%, 24 \%)$. This means that one patient out of five has developed hepatitis coinfection. Consequently, this result can be treated as a public health important disease among the study participants. This high public health problem is due to both HIV and hepatitis viruses having shared a common mode of transmission, and study participants with HIV infection have a lower immunity than non-infected individuals; this results in re-infection of hepatitis virus on the 
Table I Factor Association on Socio-Demographic and Clinical Characteristics Among Study Participants in UoG-SRH

\begin{tabular}{|c|c|c|c|c|c|c|c|}
\hline \multicolumn{2}{|c|}{ Study Participant Characteristics } & \multicolumn{2}{|c|}{ HBV or HCV Co-Infection to HIV } & \multirow{2}{*}{$\begin{array}{l}\text { Univariate } \\
\text { COR }(95 \% \mathrm{Cl})\end{array}$} & \multirow[t]{2}{*}{$P$-value } & \multirow{2}{*}{$\begin{array}{l}\text { Multivariate } \\
\text { AOR }(95 \% \mathrm{Cl})\end{array}$} & \multirow[t]{2}{*}{$P$-value } \\
\hline & & Yes $N(\%)$ & No $N(\%)$ & & & & \\
\hline Gender & $\begin{array}{l}\text { Male } \\
\text { Female }\end{array}$ & $\begin{array}{l}10 \\
7\end{array}$ & $\begin{array}{l}36 \\
28\end{array}$ & $\begin{array}{l}\text { I.II }(0.37,3.29) \\
\text { I }\end{array}$ & 0.000 & $0.87(0.18,4.31)$ & 0.869 \\
\hline Age in years & $\begin{array}{l}<36 \\
>36\end{array}$ & $\begin{array}{l}9 \\
8\end{array}$ & $\begin{array}{l}32 \\
26\end{array}$ & $\begin{array}{l}0.91(0.3 \mathrm{I}, 2.70) \\
\mathrm{I}\end{array}$ & 0.000 & $\begin{array}{l}3.49(0.56,21.99) \\
1\end{array}$ & 0.183 \\
\hline Residence & $\begin{array}{l}\text { Urban } \\
\text { Rural }\end{array}$ & $\begin{array}{l}10 \\
7\end{array}$ & $\begin{array}{l}45 \\
19\end{array}$ & $\begin{array}{l}0.60(0.20,1.82) \\
\text { I }\end{array}$ & 0.000 & $\begin{array}{l}0.34(0.28,4.3 \mathrm{I}) \\
\mathrm{I}\end{array}$ & 0.408 \\
\hline Smoker & $\begin{array}{l}\text { Yes } \\
\text { No }\end{array}$ & $\begin{array}{l}6 \\
11\end{array}$ & $\begin{array}{l}6 \\
58\end{array}$ & $\begin{array}{l}5.27(1.43,19.39) \\
\text { I }\end{array}$ & 0.012 & $\begin{array}{l}0.84(0.30,23.20) \\
\text { I }\end{array}$ & 0.918 \\
\hline Alcoholic & $\begin{array}{l}\text { Yes } \\
\text { No }\end{array}$ & $\begin{array}{l}9 \\
8\end{array}$ & $\begin{array}{l}12 \\
52\end{array}$ & $\begin{array}{l}4.87(1.56,15.25) \\
\text { I }\end{array}$ & 0.006 & $\begin{array}{l}0.56(0.42,7.4 I) \\
I\end{array}$ & 0.661 \\
\hline Condom usage & $\begin{array}{l}\text { Yes } \\
\text { No }\end{array}$ & $\begin{array}{l}5 \\
12\end{array}$ & $\begin{array}{l}49 \\
15\end{array}$ & $\begin{array}{l}0.13(0.04,0.42) \\
\mathrm{I}\end{array}$ & 0.001 & $\begin{array}{l}1.26(0.52,30.24) \\
\text { I }\end{array}$ & 0.888 \\
\hline Sharing of sharp materials & $\begin{array}{l}\text { Yes } \\
\text { No }\end{array}$ & $\begin{array}{l}5 \\
12\end{array}$ & $\begin{array}{l}7 \\
57\end{array}$ & $\begin{array}{l}3.39(0.92,12.52) \\
\text { I }\end{array}$ & 0.067 & $\begin{array}{l}9.27(0.44,19.75) \\
1\end{array}$ & 0.154 \\
\hline Wise use of HAART & $\begin{array}{l}\text { Yes } \\
\text { No }\end{array}$ & $\begin{array}{l}6 \\
11\end{array}$ & $\begin{array}{l}59 \\
5\end{array}$ & $\begin{array}{l}0.05(0.01,0.18) \\
I\end{array}$ & 0.000 & $\begin{array}{l}0.01(0.00 I, 0.213) \\
I\end{array}$ & $0.003^{*}$ \\
\hline Abstinence & $\begin{array}{l}\text { Yes } \\
\text { No }\end{array}$ & $\begin{array}{l}8 \\
9\end{array}$ & $\begin{array}{l}54 \\
10\end{array}$ & $\begin{array}{l}0.16(0.05,0.53) \\
\text { I }\end{array}$ & 0.004 & $\begin{array}{l}0.28(0.01,8.59) \\
1\end{array}$ & 0.462 \\
\hline Hygiene & $\begin{array}{l}\text { Yes } \\
\text { No }\end{array}$ & $\begin{array}{l}9 \\
8\end{array}$ & $\begin{array}{l}41 \\
23\end{array}$ & $\begin{array}{l}0.63(0.2 \mathrm{I}, \mathrm{I} .86) \\
\mathrm{I}\end{array}$ & 0.404 & - & - \\
\hline
\end{tabular}

Note: *Indicates significant association.

Abbreviations: $\mathrm{AOR}$, adjusted odds ratio; $\mathrm{Cl}$, confidence interval; $\mathrm{OR}$, odds ratio.

formerly infected individuals. Also, due to side effects of the medication that is given to the HIV-infected patients, the liver disease can worsen. ${ }^{19,20}$

Regarding the prevalence of HBV, the results obtained from this study showed that $13.5 \%$ (95\% CI: $10.5 \%$, $16.5 \%$ ) of study participants were co-infected by the HBV. The reason for the co-infection can be that the two diseases have a similar route of transmission, similar risk groups, and HIV patients are immune-compromised, which makes them susceptible to different comorbidity and other opportunistic diseases. ${ }^{14}$ Therefore, HIVinfected patients are more prone to exposure to the HBV infection than the general population; it is around $2 \%$ in the general population in Ethiopia. ${ }^{21}$ However, study participants in the current study had a $13.5 \%$ prevalence of $\mathrm{HBV}$; this means that it is around seven times greater than in the general population. When we compared the current study with similar studies, this result was greater than results from studies reported in Brazil, ${ }^{26}$ east sub-
Saharan Africa, ${ }^{27}$ and Ghana, ${ }^{28}$ which reported that the prevalence of HBV among HIV-positive patients was $3.8 \%, 2 \%$, and $6.1 \%$, respectively. However it is lower than a study conducted in Egypt that found a prevalence of $22 \%{ }^{29}$ In the same way, the current study result compared to the Ethiopian context, the finding was similar to studies done in Shashemene in which there was a $14 \%$ prevalence of hepatitis among HIV-positive detected..$^{30}$ However, this present study finding can be considered as higher than those of studies conducted in Addis Ababa, ${ }^{31}$ St Paul's General Specialized Hospital, ${ }^{32}$ and in Wolaytasodo, ${ }^{33}$ where they found prevalences of $7 \%, 3.9 \%$, and $8.4 \%$, respectively. The reason for such variations might be differences in sample size, recruitment settings, and differences in geographical location. Moreover, this study and other studies were conducted with different diagnostic test methods used to screen cases: some of the studies used rapid test kits, and others used enzyme-linked immunosorbent assay. Further, this variation might be due to the 
Table 2 Socio-Demographic and Clinical Characteristics of Study Participants in UoG-SRH

\begin{tabular}{|c|c|c|c|}
\hline \multicolumn{2}{|l|}{ Characteristics } & \multirow{3}{*}{$\begin{array}{l}\text { No. } \\
46 \\
35\end{array}$} & \multirow{3}{*}{$\begin{array}{l}\text { Frequency (\%) } \\
56.8 \% \\
43.2 \%\end{array}$} \\
\hline Sex & Female & & \\
\hline & Male & & \\
\hline \multirow[t]{3}{*}{ Age in years } & $15-35$ & 42 & $51.6 \%$ \\
\hline & $36-55$ & 32 & $39.5 \%$ \\
\hline & $>56$ & 7 & $8.6 \%$ \\
\hline \multirow[t]{2}{*}{ Residence } & Urban & 55 & $67.9 \%$ \\
\hline & Rural & 26 & $32.1 \%$ \\
\hline Smoker & Yes & 12 & $14.8 \%$ \\
\hline Alcoholic & Yes & 21 & $25.9 \%$ \\
\hline No condom usage & Yes & 27 & $33.3 \%$ \\
\hline Sharing of sharp materials & Yes & 12 & $14.8 \%$ \\
\hline Unfaithfulness & Yes & 18 & $22.2 \%$ \\
\hline Eye color (jaundice) & Yes & 14 & $17.2 \%$ \\
\hline One to one & Yes & 62 & $76.5 \%$ \\
\hline Fever & Yes & 9 & $11.1 \%$ \\
\hline Chill & Yes & 9 & $11.1 \%$ \\
\hline Diarrhea & Yes & 12 & $14.8 \%$ \\
\hline Wise use of HAART & Yes & 72 & $88.9 \%$ \\
\hline Viral load & $>1000$ & 42 & $51.8 \%$ \\
\hline & $\leq 1000$ & 39 & $48.1 \%$ \\
\hline
\end{tabular}

Notes: Wise use of HAART: an individual who uses medication as the prescription stated.

re-growing epidemicity of HIV, the rising cases of HBVpositive individuals, and poor awareness of the community towards the transmission of HBV infection.

The findings of the current study showed that the seroprevalence of $\mathrm{HCV}$ among study participants was $8.6 \%(95 \%$ CI: $5.6 \%, 11.6 \%)$. This figure showed that nearly one patient out of ten patients had developed $\mathrm{HCV}$ co-infection, and it can be considered as a public health important disease in the study area. For a similar reason with $\mathrm{HBV}$ co-infection, the high result might be due to the shared route of transmission, and being immune-compromised makes these patients more susceptible to $\mathrm{HCV}$ co-infection than the normal population. But the number of HIV-infected participants is nearly fourfold $(8.5 \%)$ the result than in the general population. The current study result was in line with study done in Malawi $^{34}$ and east sub-Saharan Africa ${ }^{27}$ among HIV- infected study participants where the results were 5.7\% and $2 \%$, respectively. Similarly, this study was in line with a study done in Ethiopia, in Gondar and Adawa, which was $5.6 \%$ and $6.6 \%$, respectively). ${ }^{35}$

Regarding HIV viral load, $88.2 \%$ (15/17) of the hepatitis co-infected groups do have an abnormal high viral load which was $>1000$ copies $/ \mathrm{mL}$. The study also found that the highest HBV and HCV magnitude is observed in individuals with a higher viral load count. The most probable reason for this higher co-infection versus higher HIV viral load is due to the fact that HIV-RNA suppresses the host immune system, leading to the acquisition and development of other infectious agents like hepatitis. This result is supported by many other studies in HIV-positive patients. Similarly, the systematic review study also indicates that having a higher viral load count is a risk for the high hepatitis co-infection.

The results revealed that a significant relationship was found between wise use of HAART and hepatitis coinfection. Having wise use of HAART can reduce the exposure of hepatitis co-infection by $99 \%(77 \%, 99.9 \%)$. This is due to the ability of the HAART treatment to reduce the HIV viral replication and the viral load count and increase the immunity of the patients, so the patients will have a lower susceptibility rate than patients with a higher viral load count. However, HIV-positive individuals who failed to use the HAART treatment are vulnerable to the acquisition of hepatitis co-infection. The results of this study also indicate the co-infection is higher among males and age groups of $<35$. Besides, it is consistent with a study reported by Yemanebrhane et al. ${ }^{36}$ This might be related to males and the $<35$ age group being the highest carriers of HIV in Ethiopia compared to females. ${ }^{37}$ Further, these groups are more expected to have behaviors that lead to the transmission of HIV and hepatitis, like intravenous drug use. ${ }^{25}$

\section{Strength and Limitations}

The first strength of this study is it determined the viral load count and its association with HBV/HIV and HCV/ HIV co-infection. Second, both the HBV and HCV coinfection were assessed. However, the study limitations are that the study used a cross-sectional study design which has a chicken-egg dilemma. Information on sensitive behaviors like alcohol abuse, condom usage, and cigarette smoking through the questionnaire may not be reported faithfully. 


\section{Conclusion and Recommendations}

The seroprevalence of hepatitis was $21 \%$ (95\% CI: $17 \%$, $23 \%$ ). This study revealed that the prevalence of hepatitis was high. Also, the wise use of HAART is significantly associated with hepatitis co-infection, and the HBV and $\mathrm{HCV}$ magnitude is seen in individuals with a high HIV viral load count. Further, the co-infection rate is most frequently observed in males and in the age group 15-45 years.

As a recommendation, for all HIV patients, screening of HBV and HCV is mandatory. Second, the health sector practitioners and policymakers should develop local guidelines and protocols for analysis and diagnosis of hepatitis co-infection. Similarly, the study suggested that any HIV patients should strictly use HAART treatment.

\section{Abbreviations}

EDTA, ethylene diamine tetra acetic acid; HAART, highly active antiretroviral therapy; $\mathrm{HBsAg}$, hepatitis B surface antigen; HBV, hepatitis B viruses; HCV, hepatitis C viruses; HIV, human immunodeficiency virus; IQR, interquartile range; SD, standard deviation; UoG-SRH, University of Gondar Specialized Referral Hospital.

\section{Data Sharing Statement}

All data supporting these findings are contained within the manuscript.

\section{Ethical Considerations}

This study was conducted per the declaration of Helsinki. Before data collection, ethical clearance and permission letters were taken from the ethical review committee of the Institute of Biotechnology, the University of Gondar (Ref. No. /912/05/2020) and UoG-SRH, respectively. Then study participants were given full information about the study and asked about their voluntariness; then they were asked to give written informed consent. For those study participants who were less than 18 years old, they were asked their willingness to participate in the study and given the assent form, and their parents or guardians also signed the informed consent. Then, in case of a positive finding, the test result was given to the patient's physician to take appropriate medications and follow-up. Also, any result of study participants was kept confidential.

\section{Consent for Publication}

Not applicable. The manuscript does not include personal data.

\section{Acknowledgments}

We would like to thank the Institute of Biotechnology and School of Biomedical and Laboratory Science, the University of Gondar. Second, we would like to thank all UoG-SRH staff and study participants who volunteered to participate in this study.

\section{Funding}

We received no funding to do this study.

\section{Disclosure}

The authors report no conflicts of interest for this work.

\section{References}

1. Soriano V, Barreiro P, Nunez M. Management of chronic hepatitis $\mathrm{B}$ and $\mathrm{C}$ in HIV-coinfected patients. J Antimicrob Chemother. 2006;57(5):815-818. doi:10.1093/jac/dk1068

2. Alter MJ. Epidemiology of viral hepatitis and HIV coinfection. $J$ Hepatol. 2006;44:56-59.

3. Saravanan S, Velu V, Kumarasamy N, et al. Coinfection of hepatitis $\mathrm{B}$ and hepatitis $\mathrm{C}$ virus in HIV-infected patients in south India. WJG. 2007;13(37):5015. doi:10.3748/wjg.v13.i37.5015

4. Gyar SD, Reuben CR, Reuben CR. Assessment of hepatitis B co-infection among HIV/AIDS patients attending antiretroviral therapy (ART) clinic in Garaku central Nigeria. Res $J$ Microbiol. 2014;9:232-238. doi:10.3923/jm.2014.232.238

5. Chung RT. Hepatitis $\mathrm{C}$ and $\mathrm{B}$ viruses the new opportunists in HIV infection. Top HIV Med. 2006;14:78-83.

6. Matthews GV, Dore GJ. HIV and hepatitis C coinfection. $J$ Gastroenterol Hepatol. 2008;23(7pt1):1000-1008. doi:10.1111/ j.1440-1746.2008.05489.x

7. Hawkins C, Christian B, Ye J, et al. Prevalence of hepatitis B co-infection and response to antiretroviral therapy among HIV-infected patients in Tanzania. AIDS. 2013;27(6):919-927. doi:10.1097/QAD.0b013e32835cb9c8

8. Stabinski L, Reynolds SJ, Ocama P, et al. High prevalence of liver fibrosis associated with HIV infection: a study in rural Rakai, Uganda. Antivir Ther. 2011;16(3):405-411. doi:10.3851/ IMP1783

9. Ocama P, Opio KC, Kagimu M, Seremba E, Wabinga H, Colebunders R. Hepatitis B virus and HIV infection among patients with primary hepatocellular carcinoma in Kampala, Uganda. Afr Health Sci. 2011;11(Suppl 1):S20-3. doi:10.4314/ ahs.v11i3.70065

10. HIV/AIDS JUNPo. Global Report: UNAIDS Report on the Global AIDS Epidemic 2013. Geneva: Joint United Nations Programme on HIV/AIDS; 2013.

11. Ministry of Health Ethiopia \& Federal HIV/AIDS Prevention and Control Office. Guidelines for paediatric HIV. AIDS care and treatment in Ethiopia; 2007.

12. Joint United Nations Programme on HIV/AIDS (UNAIDS). Global report: UNAIDS report on the global AIDS epidemic 2013. Geneva: Joint United Nations Programme on HIV/AIDS; 2013. Available from: https://www.unaids.org/sites/default/files/media_asset/ UNAIDS Global Report 2013 en 1.pdf. Accessed November 1, 2021

13. Peterlin BM, Trono D. Hide, shield and strike back: how HIV-infected cells avoid immune eradication. Nat Rev Immunol. 2003;3(2):97-107. doi:10.1038/nri998 
14. Belayneh F. Prevalence of hepatitis B virus infection and associated factors among HIV positive adults attending ART clinic at Hawassa referral hospital, SNNPR, Ethiopia. Open Access Library J. 2015;2(05):1.

15. Tigabu A, Engda T, Mekonnen F. Seroprevalence of transfusion transmissible viral infections (HIV, HBV and HCV) among voluntary blood donors at University ofGondar Comprehensive SpecializedHospital, Gondar; Northwest Ethiopia. BMC. 2019;19(393):1-8.

16. Askari A, Hakimi H, Ahmadabadi BN, Hassanshahi G, Arababadi MK. Prevalence of hepatitis B co-infection among HIV positive patients: narrative review article. Iran J Public Health. 2014;43(6):705.

17. Endeshaw Abatenh AA, Hiluf L, Mohammed N. Hepatitis B co-infection in HIV AIDS patients in Woldia. Ethiop Microbiol Biotechnol Rep. 2016;2(3):5.

18. Burnett R, Francois G, Kew M, et al. Hepatitis B virus and human immunodeficiency virus co-infection in sub-Saharan Africa: a call for further investigation. Liver Int. 2005;25(2):201-213. doi:10.1111/ j.1478-3231.2005.01054.x

19. Gopalappa C, Farnham PG, Chen Y-H, Sansom SL. Progression and transmission of HIV/AIDS (PATH 2.0) a new, agent-based model to estimate HIV transmissions in the United States. Med Decis Making. 2017;37(2):224-233. doi:10.1177/0272989X16668509

20. Matida LH, da Silva MH, Tayra AN, et al. Prevention of mother-tochild transmission of HIV in São Paulo State, Brazil: an update. AIDS. 2005;19:S37-S41. doi:10.1097/01.aids.0000191489.59112.13

21. Belayneh F. Prevalence of hepatitis B virus infection and associated factors among HIV positive adults attending ART clinic at Hawassa Referral Hospital, SNNPR, Ethiopia. Res Gate. 2015;2:e1490.

22. Population Census Commission. Summary and statistical report of the 2007 population and housing census. Population size by age and sex. 2008:314.

23. Macrotrends. Gondar, Ethiopia metro area population 1950-2021. Avaiable from: https:/www.macrotrends.net/cities/20926/gondar/ population. Accessed October 26, 2021.

24. Wagnew FDG, Eshetie S, Alebel A, Worku W, Abajobir AA. Treatment cure rate and its predictors among children with severe acute malnutrition in northwest Ethiopia: a retrospective record review. PLoS One. 2019;14 (2):e0211628. doi:10.1371/journal.pone.0211628

25. Wondimeneh Y, Alem M, Asfaw F, Belyhun Y. HBV and HCV seroprevalence and their correlation with CD4 cells and liver enzymes among HIV positive individuals at University of Gondar Teaching Hospital, Northwest Ethiopia. Virol J. 2013;10(1):171. doi:10.1186/1743-422X-10-171

26. Zago AM, Machado TF, Cazarim FL, Miranda AE. Prevalence and risk factors for chronic hepatitis B in HIV patients attended at a sexually-transmitted disease clinic in Vitoria, Brazil. Braz J Infect Dis. 2007;11(5):475-478.

27. Mohd Hanafiah K, Groeger J, Flaxman AD, Wiersma ST. Global epidemiology of hepatitis $\mathrm{C}$ virus infection: new estimates of agespecific antibody to HCV seroprevalence. Hepatology. 2013;57 (4):1333-1342. doi:10.1002/hep.26141

Hepatic Medicine: Evidence and Research

\section{Publish your work in this journal}

Hepatic Medicine: Evidence and Research is an international, peerreviewed, open access journal covering all aspects of adult and pediatric hepatology in the clinic and laboratory including the following topics: Pathology, pathophysiology of hepatic disease; Investigation and treatment of hepatic disease; Pharmacology of drugs used for the
28. Pappoe F, Hagan CKO, Obiri-Yeboah D, Nsiah P. Sero-prevalence of hepatitis $\mathrm{B}$ and $\mathrm{C}$ viral infections in Ghanaian HIV positive cohort: a consideration for their health care. BMC Infect Dis. 2019;19(1):380. doi:10.1186/s12879-019-4027-y

29. Magder LS, Fix AD, Mikhail NN, et al. Estimation of the risk of transmission of hepatitis $\mathrm{C}$ between spouses in Egypt based on seroprevalence data. Int $J$ Epidemiol. 2005;34(1):160-165. doi:10.1093/ije/dyh370

30. Negero A, Sisay Z, Medhin G. Prevalence of hepatitis B surface antigen (HBsAg) among visitors of shashemene general hospital voluntary counseling and testing center. BMC Res Notes. 2011;4(1). doi:10.1186/1756-0500-4-35

31. Almamedova E, Antonyak S, Bobrova A, et al. Management of Hepatitis $B$ and HIV Coinfection. Copenhagen: WHO Regional Office for Europe; 2011:2.

32. Shimelis T, Torben W, Medhin G, et al. Hepatitis B virus infection among people attending the voluntary counselling and testing centre and anti-retroviral therapy clinic of St Paul's General Specialized Hospital, Addis Ababa, Ethiopia. Sex Transm Infect. 2008;84:37-41. doi:10.1136/sti.2007.027326

33. Goa A, Dana T, Bitew S, Arba A. Seroprevalence and associated factors of hepatitis B virus infection among HIV-positive adults attending an antiretroviral treatment clinic at Wolaita Sodo University Referral Hospital. Hepatic Med Evid Res. 2019;11:137. doi:10.2147/HMER.S206870

34. Davies J, van Oosterhout J, Nyirenda M, et al. Reliability of rapid testing for hepatitis B in a region of high HIV endemicity. Trans $R$ Soc Trop Med Hyg. 2010;104(2):162-164. doi:10.1016/j. trstmh.2009.10.010

35. Atsbaha AH, Dejen TA, Belodu R, Getachew K, Saravanan M, Wasihun AG. Sero-prevalence and associated risk factors for hepatitis $\mathrm{C}$ virus infection among voluntary counseling testing and anti retroviral treatment clinic attendants in Adwa hospital, northern Ethiopia. BMC Res Notes. 2016;9(1):121. doi:10.1186/s13104-016-1936-3

36. Yemanebrhane N, Addise D, Abebe N, Abebe F, Shewaamare A, Tsegaye A. Magnitude of hepatitis $\mathrm{B}$ virus and hepatitis $\mathrm{C}$ virus among HAART taking patients and association with liver and renal function and CD4+ T cells level. J AIDS Clin Res. 2017;8(06). doi:10.4172/2155-6113.1000702

37. Taye S, Lakew M. Impact of hepatitis $\mathrm{C}$ virus co-infection on HIV patients before and after highly active antiretroviral therapy: an immunological and clinical chemistry observation, Addis Ababa, Ethiopia. BMC Immunol. 2013;14(1):23. doi:10.1186/ 1471-2172-14-23

treatment of hepatic disease. Issues of patient safety and quality of care will also be considered. The manuscript management system is completely online and includes a very quick and fair peer-review system, which is all easy to use. Visit http://www.dovepress.com/ testimonials.php to read real quotes from published authors. 